\title{
Dimensions of Intergenerational Farm Business Transfers in Canada, England, the USA and Japan
}

\author{
Tomohiro Uchiyama, ${ }^{*}$ Matt Lobley, ${ }^{\dagger}$ Andrew Errington \\ and Shunsuke Yanagimura ${ }^{\ddagger}$
}

\begin{abstract}
Despite widespread concern that fewer and fewer individuals wish to enter farming as a career, intergenerational succession remains an important objective for many farm businesses. Indeed, it can be argued that intergenerational transfer represents a fundamental aspect of the social sustainability of family farming. Previous research has frequently focused on the transfer of physical assets, while less attention has been devoted to the transfer of the intangible assets of the farm business such as managerial skills and farm-specific knowledge. This paper focuses on the succession process after a successor has been identified and analyses patterns of behaviour regarding the delegation of management responsibility. Data from the international comparative studies is used to compare the main routes to succession in four countries and identifies how different routes to succession can influence the delegation of managerial responsibility. In doing so, the paper reflects on the 'farmer's boy' problem and considers the implications for the successful transfer and survivability of the farm business.
\end{abstract}

Key words : farm family business, succession, retirement, intangible assets, managerial skills, routes to succession, delegation.

\section{Introduction}

Intergenerational succession arguably represents an integral facet of the family farm. Previous research has indicated that a major concern for the family business generally is to ensure that it is passed down successfully from one generation of 'chief executive' to the next (Gasson and Errington [13]; Väre $[30])$, a process which often triggers new phases of business development (Potter and Lobley [26]). In the case of the family business, their unique characteristics are such that in most cases the successor is a child of the manager and physical assets as well as intangible assets (e.g. tacit knowledge) are transferred to the new 'chief executive'. In particular, the succession issue is likely to be more important in the family business because the generation gap between the manag-

\footnotetext{
${ }^{*}$ Mie University

${ }^{\dagger}$ Exeter University

${ }^{\ddagger}$ Miyagi University
}

er and the successor is larger and the assets to be transferred more varied than in corporate businesses. When the fact that most farming business are operated by families is taken into consideration, it can be argued that intergenerational farm transfers are a fundamental aspect of the sustainability of farm businesses. In turn, many commentators argue that sustaining family farms contributes to the broader sustainability of rural communities (e.g. Ramos [28]).

In England, the approach taken by the Department of the Environment, Food and $\mathrm{Ru}-$ ral Affairs (Defra) does not extol the virtues of any particular size structure of farms and does not promote 'family' farms above other forms of farming, although it has been suggested recently that there is a need for debate and clarification regarding the types of farming structure that will best deliver public good and safe, high quality food (Food Ethics Council [12]). In neighbouring Wales the $\mathrm{Na}-$ tional Assembly appears to firmly favour the family farm arguing that "the family farm 
defines the character of Welsh rural society, and its sense of identity. The numbers directly and indirectly involved in farming make a crucial contribution towards sustaining rural communities" (National Assembly for Wales [22]). This approach is arguably more typical of many members of the EU whereas Defra's lack of explicit support for family farms is likely to bring it into conflict with EU partners (Food Ethics Council [12]). Beyond Europe, strong connections are also made between sustaining family farms and rural sustainability. For instance, in the United Sates, where family farmers have long held a special place in the nation, it has recently been re-stated that family farms are "...still a vibrant and necessary part of society $\cdots$ the contribution of farm businesses to the rural economy, the environment and, indeed, to society as a whole should not be ignored. Those who live next to the land and toil upon it are more likely to be interested in their community, their environment and their society..." (Baker [2]). In Japan, the government "Basic Plan for Food, Agriculture and Rural Areas" aspires to promote the "principal farmers, " most of those are family-based commercial management, for stimulating rural economies and conserving rural resources.

The process of intergenerational transfer represents the renewal of the family farm and the associated transfer of farm-specific, or "soil-specific" human capital can confer an advantage on an intergenerational successor (Laband and Lentz [19]). The highly detailed and locally specific knowledge associated with successful intergenerational transfers can prove vital for effective environmental management and, thorough engendering a sense of intergenerational accountability, can position farmers as interpreters and exemplars of local history, nature and culture (see Burton et al. [6]). In addition, farm business performance is influenced by succession issues (Boehlje and Eidman [5]), not least the potential for conflict between the generations. As Nalson [21] observed, farm succession is "both an effect of previous causes.. and a cause of subsequent effects". Thus, farm succession and farm business development influence each other and consequently, the process of succession has implications for the social and economic sustainability of the family farm.

Despite the apparent importance of intergenerational succession both as a mechanism for transferring tangible and intangible farming assets and as an objective in itself, relatively little attention has been paid to the pattern and process of farm succession. Moreover, much less attention has been paid to international comparisons of the succession process. Those studies that have been undertaken tend to have been conducted within a single country. One reason for this could be that variation in the cultural norms and values which influence succession (Salamon [29]) would make international comparisons difficult to cope with. However, given the importance attached to farm succession in developed countries a comparative overview of succession patterns provides a useful starting point for more culturally informed local level studies. Against this background, the aim of this paper is to examine the similarities and differences in the factors which influence behaviour toward farm business succession in developed countries using data from a number of national studies of farm succession patterns.

\section{Succession Patterns, Contents and Stages}

Previous literature on farm succession issues points to variations in the pattern of intergenerational transfer of farm ownership and management between countries, and even within the same country (Blanc and PerrierCornet [4]; Gasson and Errington [13]; Potter and Lobley [26]; Salamon [29]). As Errington and Lobley [10] point out, there appear to be two key distinctions in these patterns in the existing literature, namely the amount of responsibility exercised by the successor in taking decisions on the "home farm" (i.e. the extent of delegated decision taking) and the extent to which he or she has the opportunity to run a separate enterprise or even a separate farm (referred to as a "stand by holding" by Gasson and Errington [13]). Different succession patterns are significant in as far as these patterns affect the smoothness of the farm succession process, farmers' behaviour and their responsiveness to particular policy measures, the performance and survivability of farm businesses and environmental management (Potter and 
Lobley [26]). However, there has been relatively little analysis of what factors might influence the succession patterns observed.

In terms of the assets that are transferred in the process of intergenerational farm transfers, much of the literature highlights the transfer of physical assets such as agricultural land, reflecting the unique characteristics of farming which requires large amounts of capital and longer periods of repayment. For example, Harl [15] identified three goals to be achieved through farm succession: (1) security for living after retirement, 1) (2) "equitable" treatment for children, and (3) minimum cost for transferring and sorting out business assets, e.g. minimising inheritance tax. These goals focus more on physical assets, reflecting the fact that long-standing social norms (such as primogeniture) have been increasingly challenged, particularly as agricultural support measures in many countries have been capitalised into land values thus inflating the value of the farm and creating significant hurdles if the succeeding heir has to buy-out other siblings.

Much less attention however, has been paid to the intergenerational transfer of the intangible resources associated with the farm business. These include assets that are difficult to observe but which can nevertheless influence future farming performance. In family farming businesses, where the number of individuals involved in any one business is relatively small, the importance of human capital, which includes the skills, talents and tacit knowledge that has been developed by the farmer in working a particular area of land, should not be underestimated, particularly in the context of undertaking locally appropriate sustainable land management practices. Generally speaking, farmers draw on two forms of knowledge: farming practice in general (i.e. codified or standardised knowledge) and tacit, farm specific knowledge such as a detailed knowledge of the home farm, its individual fields and micro-climate and its idiosyncrasies. In the case of agriculture, Laband and Lentz [19] have argued that farm-specific knowledge is of far greater value than firm-specific knowledge in other sectors. Moreover, the larger the farm business, the more vital managerial skills and knowl- edge become, as opposed to the physical assets themselves, and the more important the smooth and timely transfer of such skills. Thus, Winter [32] has highlighted the importance of farmers' knowledge transfer in relation to running the farm business under the circumstances of farmer isolation; and Kennedy [17: p. 133] reasoned that "family members may have accumulated farm-specific capital, in the sense of productive skills and knowledge peculiar to the home farm, which gave them an efficiency advantage over nonkin." These findings suggest that a focus on the intangible resources (specifically managerial competencies and associated knowledge) and the transfer of these resources between generations may help provide clues to the future survivability of the farm business. Therefore this paper focuses on the transfer of intangible resources, not that of the physical assets. In doing so, the paper aims to contribute to the debate concerning the sustainability of farm family businesses.

Measuring intangible resources and tracking their transfer between the generations is far from straightforward. In this paper therefore we use the degree of delegation of managerial competencies from a farmer to his/her successor as an indicator to measure the transfer of the intangible resources of the farm. As Laband and Lentz [19] explain, if there are many farm-specific resources, which could substitute for or enhance formal education in farming businesses and if experience is needed to acquire such tacit knowledge through learning by doing, the progress of delegation of management responsibility could be an indication of the transfer of intangible resources. Certainly, there is evidence that farmers are not normally good "delegators" (Giles and Stansfield [14: p. 178]), and for this reason, observing the degree of delegation can provide a valuable indication of the process of transferring intangible resources.

Elaboration of the succession process in the farm family businesses is provided by $\mathrm{Du}$ mas, Richer, and St.-Cyr [8] who classify it into four stages: "incubation," "the choice of successor," "joint management," and "the predecessor's departure," reflecting the progressive importance of the acquisition of knowledge and demonstration of management competencies. While the interaction of farm 
specific factors (such as size), demographic and economic factors are useful in explaining the determinants of potential successor choice at the "incubation" and "the choice of successor" stages, the focus of the present paper is on the later stages when the "successor effect" (Potter and Lobley [27]) becomes apparent (the impact successors themselves have on assuming partial or total management control). To investigate "by what process" business management is transferred, it is important to focus on "the joint management" stage, which begins when the successor works full-time in the business, and "the predecessor's departure" stage, which involves the disengagement and departure of the predecessor, mostly influenced by illness, old age or death. In particular, this paper examines the extent to which the identification of a successor influences the farmer's retirement plans and the delegation of managerial responsibilities between farmers and successors.

\section{Methodology and Data Outline}

The data which are used in this paper have been collected through the FARMTRANSFERS project, which involves a series of international comparative studies replicating a survey by Errington and Tranter [11], which explored the mechanisms by which farm businesses were being transferred from one generation to the next among a sample of English farmers. The details of the survey in each country have been already noted in other papers (Baker, Duffy, and Lamberti [3]; Errington [9]; VDACS [31]; Yanagimura et al. [33]). Briefly, data is collected through a postal questionnaire covering basic background information about the farm (e.g. size and tenure) and farm family demographics (age, household composition, etc). Detailed information is recorded regarding retirement and succession plans and the current involvement of successors in the farm business. Modifications to the copyrighted FARMTRANSFERS questionnaire to reflect national social, cultural and economic differences are made with the agreement of the project directors. It should be noted that the sample size and year of survey for each country reported here is: Canada: 1, 270 (1997), England: 491 (1997), USA, Iowa: 418 (2000),
USA, Virginia: 404 (2001), Japan : 5,006 (2001). Whilst it is important to acknowledge the limitations of the methodology, such as 1) the survey year differing according to the countries and regions, and 2) the unified postal questionnaire format imposing limitations in terms of collecting detailed historical and cultural information on farm succession and farmer retirement in each country, this approach nevertheless yields a range of quantitative data relating to the pattern, process and speed of succession and retirement which provides a firm base for future in-depth inquiries. Errington and Lobley [10] have already made a basic comparison of the results of England, France, Canada and the USA (Iowa). This paper broadens that analysis by including Virginia and Japan and adds to its depth by exploring the factors which influence farmers' succession behaviour.

Table 1 presents the outline of the data used in this paper. As can be seen, there are notable differences in farm size between the surveyed countries and regions. Particularly striking is the fact that mean farm size is very much smaller in Japan than in the other countries, even taking into account the fact that holdings of less than 0.1 ha have been excluded from the analysis. This reflects the fact that the Japanese data include many horticultural farms as well as small-scale rice producers. We have therefore taken the number of full-time worker equivalents (including the farmer him/herself) as an index of farm business size. The questionnaire is directed towards the principal farmer and as Table 1 shows the mean age of respondents is lower in Canada and higher in the USA and Japan, reflecting the fact that farmers are ageing more in the latter.

Throughout this paper, tests of significance refer to $\mathrm{Chi}^{2}$ tests with the $5 \%$ or $1 \%$ limit taken as indicating statistical significance.

\section{Characteristics of Farmers and Successors' Behaviour}

\section{1) Identification of a successor}

Clearly, the first stage of the succession process involves the identification of a successor. Considering the proportion of respondents in each country/region that had already identified a successor reveals some substantial differences. The percentage is larger in 
Dimensions of Intergenerational Farm Business Transfers in Canada, England, the USA and Japan 37

Table 1. Data outline

\begin{tabular}{llllll}
\hline & & $\begin{array}{l}\text { Total area } \\
\text { farmed (ha) }\end{array}$ & $\begin{array}{l}\text { Respondent's } \\
\text { age }\end{array}$ & $\begin{array}{l}\text { Successor's } \\
\text { age }\end{array}$ & $\begin{array}{l}\text { Number of } \\
\text { fulltime labour }\end{array}$ \\
\hline Japan & Mean & 4.9 & 57.1 & 31.5 & 2.6 \\
2001 & $n$ & 4,108 & 4,136 & 1,848 & 4,351 \\
& Std. Deviation & 12.8 & 10.7 & 10.5 & 1.4 \\
\hline USA: & Mean & 189.3 & 54.0 & 31.3 & 2.5 \\
Iowa & $n$ & 389 & 413 & 110 & 404 \\
2000 & Std. Deviation & 205.0 & 14.5 & 13.4 & 1.1 \\
\hline USA: & Mean & 64.9 & 59.8 & 35.3 & 1.8 \\
Virginia & $n$ & 392 & 398 & 120 & 401 \\
2001 & Std. Deviation & 109.3 & 12.9 & 13.2 & 1.1 \\
\hline England & Mean & 163.8 & 55.1 & 32.1 & 3.2 \\
1997 & $n$ & 487 & 491 & 247 & 487 \\
& Std. Deviation & 182.6 & 12.4 & 17.3 & 1.4 \\
\hline Canada: & Mean & 122.8 & 50.7 & 25.4 & 2.6 \\
Ontario & $n$ & 530 & 530 & 197 & 519 \\
1997 & Std. Deviation & 136.2 & 12.7 & 11.2 & 1.2 \\
\hline Canada: & Mean & 116.8 & 46.9 & 22.9 & 2.9 \\
Quebec & $n$ & 698 & 726 & 285 & 719 \\
1997 & Std. Deviation & 120.0 & 11.1 & 9.3 & 1.2 \\
\hline & Mean & 52.3 & 55.3 & 30.4 & 2.6 \\
Total & $n$ & 6,604 & 6,694 & 2,806 & 6.881 \\
& Std. Deviation & 114.1 & 12.0 & 11.8 & 1.4 \\
\hline
\end{tabular}

Source: FARMTRANSFERS.

England (52.8\%) and Japan (49.8\%) than it is in either of the Canadian provinces $(39.8 \%$ in Ontario and $42.1 \%$ in Quebec). This is perhaps to be expected because, as we have already seen, farmers in Canada tended to be younger. However, the proportion was also very much lower in the USA $(28.8 \%$ in Iowa and $30.8 \%$ in Virginia) where the farmers, in fact, tend to be rather older.

Obviously, the likelihood of having identified a successor is in part a function of the age of the farmer which, as we have seen, varies considerably between countries. Figure 1 therefore examines the identification of successor by age of respondent and by country. It should be noted that the trend in the percentage of successors identified by each age-group is similar in Japan, England and Canada. The states of Iowa and Virginia are distinctly different however, with a much lower proportion of farmers identifying a successor. ${ }^{2)}$ When the identification of a successor by farm business size and by country is considered, the data confirms the trend that larger farms are more likely to have identified a successor (data not shown). However, causation is not clear. Are larger farms more likely to secure a successor or do the farms securing a successor become larger? In other words, it is not evident whether the trend reflects what Potter and Lobley [27] term the "succession effect" ${ }^{3)}$ or "successor effect."

\section{2) Farmers' retirement plans}

Table 2 shows the respondents' retirement plan by country. "Semi-retirement" means that the respondents become less involved in manual work on the farm while they may continue to be engaged in other farm work. Retirement intentions among the countries covered by the FARMTRANSFERS surveys can be classified into two groups. In both Ja- 


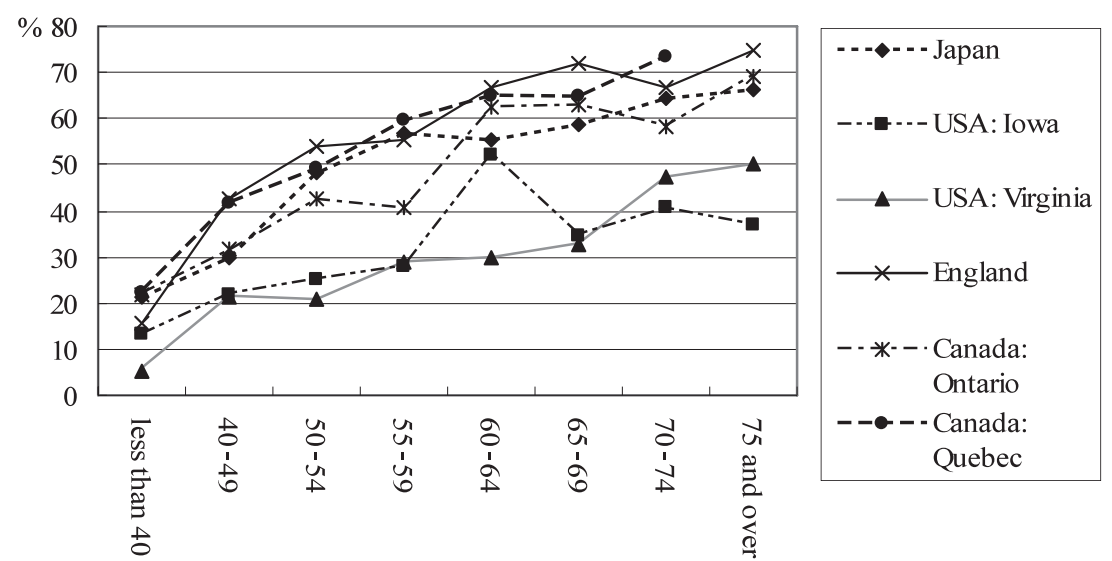

Figure 1. Proportion of farmers who have identified a successor, by age-group Source : FARMTRANSFER.

Table 2. Retirement plans

\begin{tabular}{lllllll}
\hline & Japan & $\begin{array}{l}\text { USA: } \\
\text { Iowa }\end{array}$ & $\begin{array}{l}\text { USA: } \\
\text { Virginia }\end{array}$ & England & $\begin{array}{l}\text { Canada: } \\
\text { Ontario }\end{array}$ & $\begin{array}{l}\text { Canada: } \\
\text { Quebec }\end{array}$ \\
\hline Never retire & 44.5 & 27.4 & 42.1 & 14.9 & 22.1 & 13.3 \\
Semi-retire & 37.1 & 37.6 & 33.9 & 47.1 & 44.0 & 49.5 \\
Full-retire & 18.5 & 35.0 & 23.9 & 38.0 & 33.8 & 37.2 \\
\hline$n$ & 3,826 & 391 & 401 & 450 & 529 & 721 \\
\hline
\end{tabular}

Source: FARMTRANSFERS.

pan and the USA, a much smaller proportion of farmers state that they will "semi-retire" than is the case in England and Canada. Analysing the association between these retirement plans and the identification of a successor, reveals that the respondents who have identified a successor tend to prefer semi-retirement regardless of nationality and the difference between the group who have identified a successor and those who have not is statistically significant at the $5 \%$ level in each country. It is likely that farmers' intentions toward semi-retirement are reinforced by the presence of successor. The reason for this could be that the semi-retirement option becomes easier to take when there is a successor who could "semi-takeover" the farming business. It is therefore reasonable to suppose that the securing of a successor has a major effect on the farmer's retirement options. ${ }^{4)}$ The reason why such a large proportion of Japanese farmers report that they will "never retire" could be based on the fact that there are many people who become in- volved in farming after enforced retirement from an off-farm job and that there is a seen to be a particular virtue in "Shogai-Gen-eki" (a tendency of the Japanese in general to keep working as long as possible). Figure 2 shows farmers' intention toward semi-retirement by successor's present occupation. With the exception of Ontario, we can observe the tendency for farmers to be less likely to prefer semi-retirement if their successors are involved in off-farm employment. This again emphasises the importance of the potential successor's career path in influencing and facilitating the retirement options open to the older generation of farmers. This view is supported by the tendency of farmers whose successors are students to prefer semiretirement. The student-successor has the opportunity to get involved in farming on a fulltime basis after leaving education and this would allow the current senior farmer to semi-retire.

3) Routes to succession

It is important to trace which route the 
Dimensions of Intergenerational Farm Business Transfers in Canada, England, the USA and Japan 39

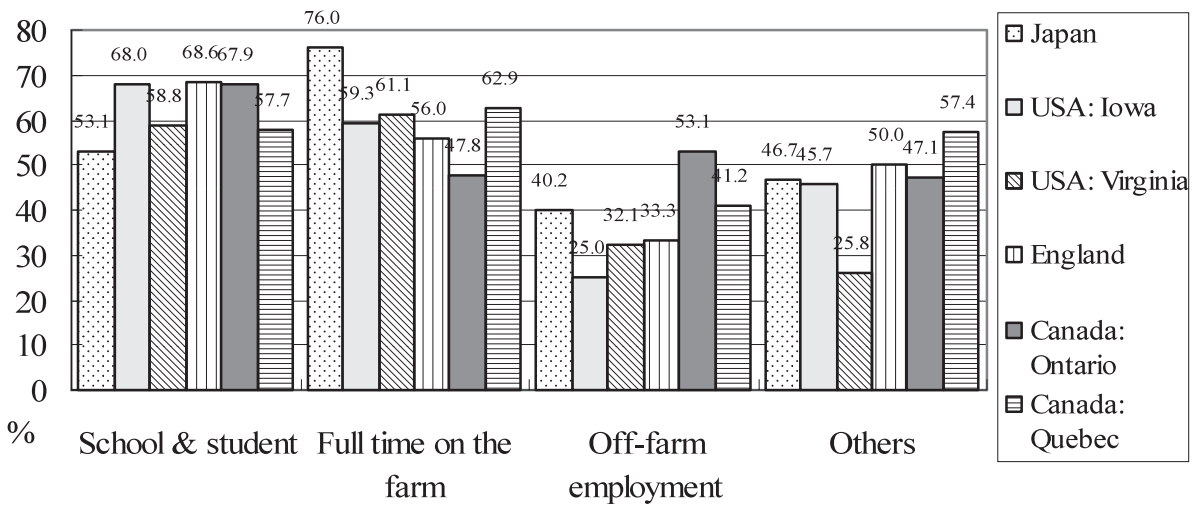

Figure 2. Preference of semi-retirement, by successors' occupation Source : FARMTRANSFER.

Table 3. Successors' present occupation

\begin{tabular}{l|rrlccc}
\hline & Japan & $\begin{array}{l}\text { USA: } \\
\text { Iowa }\end{array}$ & $\begin{array}{l}\text { USA: } \\
\text { Virginia }\end{array}$ & England & $\begin{array}{c}\text { Canada: } \\
\text { Ontario }\end{array}$ & $\begin{array}{c}\text { Canada: } \\
\text { Quebec }\end{array}$ \\
\hline Student & 9.4 & 21.0 & 13.9 & 14.2 & 25.6 & 26.1 \\
Works full time on this farm & 17.5 & 24.4 & 14.8 & $\underline{62.2}$ & $\underline{33.8}$ & $\underline{45.2}$ \\
Works on another farm & 1.2 & 5.0 & - & 4.1 & 2.9 & 1.7 \\
Off farm employment & 60.8 & 22.7 & $\underline{45.9}$ & 4.1 & 15.9 & 6.0 \\
Post compulsory education & 4.0 & 1.7 & 4.1 & 3.7 & 6.3 & 11.4 \\
Manages own farm & 0.3 & 14.3 & 4.9 & 6.1 & 8.2 & 5.0 \\
Runs non-farm business & 5.3 & 3.4 & 12.3 & 4.1 & 3.4 & 1.7 \\
Travelling & 0.1 & - & - & - & 1.0 & - \\
Other & 1.5 & 7.6 & 4.1 & 1.6 & 2.9 & 3.0 \\
\hline Total & 100.0 & 100.0 & 100.0 & 100.0 & 100.0 & 100.0 \\
\hline$n$ & 1,733 & 119 & 122 & 246 & 207 & 299 \\
\hline
\end{tabular}

Source: FARMTRANSFERS.

people who are identified as successors take to becoming 'a farmer.' Table 3 indicates the successor's present occupation by country and, as can be seen, there are some substantial differences between countries and states in this respect. In Japan and Virginia for example, a much higher proportion of successors are involved in off-farm employment, while in Iowa a relatively high proportion are managing their own farm. In Canada and England it is much more common for the successor to be working full-time alongside the older generation on the "home farm." From this data there appears to be two major routes for successors to take, namely (1) the "Direct Route", in which successors get involved in farming just after they leave school, and (2) the "Diversion Route," in which successors get involved in off-farm employment after leaving school and come back to the home farm at a later stage. Some authors (e.g. Gasson and Errington [13]) refer to this as a "professional detour" or "U-Turn" (e. g. Kurokawa [18]).

One of the factors which influence the route to succession is farm business size since smaller farms are likely to provide less opportunity for two generations to work sideby-side. ${ }^{5)}$ Analysis of the association between the proportion of successors in off-farm employment and farm business size shows that the successors from smaller farm businesses are more likely to be involved in off-farm employment (this finding is statistically significant at the 5\% level except in England and Virginia). However, it is not clear 
whether the successors are more involved in off-farm employment because their home farm business size is small, or the farm business size is small as a result of the successors being involved in off-farm employment. In addition, even if we apply the former logic, in itself it cannot explain why the percentage of successors with off-farm employment is so much higher in Japan and Virginia than it is in the other areas surveyed. In order to understand this we need to consider the general economic conditions prevailing outside the farm business as well as the cultural norms and practices characteristic of the different farming communities (Gasson and Errington [13]; Salamon [29]). However, regardless of the reason for the 'professional detour' or diversion route, the timing of the successor's return to the farm in order to take it over is crucial. When the proportion of successors in off-farm employment by the time remaining until the farmer's anticipated retirement is examined, in the locations where most of the successors are involved in off-farm employment, such as in Japan and Virginia, a majority of the successors continue working in off-farm employment, even in cases where it is less than 5 years before the farmer's retirement (57.6\% in Japan, and 58.3\% in Virginia). This suggests that there is little opportunity for the successors to work alongside the farmer and benefit from a transfer of intangible resources such as farm-specific skills and knowledge.

As discussed above, there are two major routes which the successor can take, the direct route and the diversion route. The succession pattern and its associated challenges is therefore likely to vary according to the routes the successor chooses. For example, a successor on the direct route has more opportunity for intangible resources to be transferred and greater opportunity to learn about the farm's environment through close observation over an extended period of time. A successor following the diversion route will have less opportunity to acquire these intangible resources. However, they will have more opportunity to acquire a different set of skills from outside the home farm, skills which may be particularly helpful at times when farming needs to adjust to different circumstances.

\section{Transferring Knowledge and Managerial Responsibility between Farmer and Successor}

Since effective farm management requires the skills and knowledge learned from experience and related to a particular farm as well as from formal education and training (i. e. a combination of tacit and codified knowledge), the delegation of managerial responsibility is a vital mechanism for transferring farm-specific managerial know-how in a farm business. In order to explore the process of delegating managerial responsibility and associated competencies, a series of farm business functions originally identified by Hastings [16] is focused on and the transfer of managerial responsibility is analysed.

Respondents were asked to indicate the extent to which the different decisions had been delegated to the successors working alongside the older generation on the home farm. They did this by assigning a score ranging from 1 , which means the farmers themselves retain full responsibility, to 5, which means the successors have full responsibility. Scores between 2 and 4 indicate that the farmer and successor shared responsibility. The analysis presented here classifies 11 items out of the original 176) identified by Hastings [16] into four groups ("technical," "strategic," "marketing" and "financial") as shown in Table 4 and calculates the mean scores of the items which are included in the same group, indicating the degree of managerial delegation in each of these five functional areas. The mean value of these five scores indicates the overall level of managerial delegation for the case as a whole.

\section{1) Delegation scores}

Table 5 shows the mean score of managerial responsibility by country/state. The results are consistent with previous studies, such as Anderson and Hepworth [1], which revealed that the financial field is the last knowledge and decision-making domain to be delegated. It is also largely consistent with the model of the "succession ladder" (Errington [9]) where delegation begins with the "technical" and finishes with the "financial" domain. Table 5 reconfirms the existence of the succession ladder except in Japan, though the difference is not statistically significant. 
Dimensions of Intergenerational Farm Business Transfers in Canada, England, the USA and Japan 41

Table 4. Domains of farming business functions

\begin{tabular}{|c|c|c|c|c|}
\hline & Technical & Strategic & Marketing & Finance \\
\hline Plan day-to-day work & $x$ & & & \\
\hline Make annual crop/stock plans & & $x$ & & \\
\hline Decide the mix and type of enterprises in the longer-term & & $x$ & & \\
\hline Decide type and level of feed/fertilisers/sprays/drugs used & $x$ & & & \\
\hline Decide timing of operations activities & $x$ & & & \\
\hline Decide when to sell crops/livestock & & & $x$ & \\
\hline Negotiate sales of crops/livestock & & & $x$ & \\
\hline Decide when to pay bills & & & & $x$ \\
\hline Decide work method/way jobs are done & $x$ & & & \\
\hline Decide and plan capital projects & & & & $x$ \\
\hline Identify source and negotiate loans and finance & & & & $x$ \\
\hline
\end{tabular}

Source: Adopted by Hasting [16].

Table 5. Responsibility scores of delegation

\begin{tabular}{|c|c|c|c|c|c|c|}
\hline & & Technical & Strategic & Marketing & Finance & General \\
\hline \multirow{3}{*}{ Japan } & Mean & 2. 06 & 2. 09 & 2.09 & 1.99 & 2. 03 \\
\hline & Std. Deviation & 1. 06 & 1. 07 & 1.16 & 1. 01 & 1.00 \\
\hline & $n$ & 909 & 878 & 634 & 765 & 915 \\
\hline \multirow{3}{*}{$\begin{array}{l}\text { USA: } \\
\text { Iowa }\end{array}$} & Mean & 2. 12 & 2. 03 & 1.98 & 1. 87 & 2. 01 \\
\hline & Std. Deviation & 1.28 & 1. 23 & 1.30 & 1. 18 & 1.17 \\
\hline & $n$ & 130 & 127 & 126 & 128 & 131 \\
\hline \multirow{3}{*}{$\begin{array}{l}\text { USA: } \\
\text { Virginia }\end{array}$} & Mean & 2. 02 & 1.95 & 1.87 & 1.79 & 1.91 \\
\hline & Std. Deviation & 1.05 & 0.94 & 1.08 & 0.99 & 0.91 \\
\hline & $n$ & 71 & 71 & 71 & 71 & 71 \\
\hline \multirow{3}{*}{ England } & Mean & 2.75 & 2.50 & 2. 31 & 1.95 & 2. 38 \\
\hline & Std. Deviation & 1.18 & 1.15 & 1.21 & 1.00 & 1. 02 \\
\hline & $n$ & 181 & 180 & 180 & 180 & 181 \\
\hline \multirow{3}{*}{$\begin{array}{l}\text { Canada: } \\
\text { Ontario }\end{array}$} & Mean & 3.14 & 3. 04 & 2.87 & 2.68 & 2. 92 \\
\hline & Std. Deviation & 1.14 & 1.16 & 1.35 & 1.16 & 1.09 \\
\hline & $n$ & 92 & 91 & 89 & 92 & 93 \\
\hline \multirow{3}{*}{$\begin{array}{l}\text { Canada: } \\
\text { Quebec }\end{array}$} & Mean & 2.94 & 2.83 & 2.66 & 2. 40 & 2. 69 \\
\hline & Std. Deviation & 0.86 & 0.96 & 1.11 & 0.95 & 0.84 \\
\hline & $n$ & 169 & 161 & 164 & 168 & 170 \\
\hline
\end{tabular}

Note: Ranged from 1 (no sharing of responsibility with the successor) to 5 (responsibility for all decisions delegated completely to the successor).

Source: FARMTRANSFERS.

There is a unique situation in Japan, where most farmers are members of an agricultural cooperative and traditionally sell products through agricultural cooperatives and concentrate on production. It might be that the delegation of decision-making in the technical domain is therefore slower than that in the marketing domain as a result.

2) The effect of successors' own enterprise on knowledge and managerial transfer

Table 6 shows the mean delegation scores, by whether the successor has responsibility for an individual enterprise of their own or 
Table 6. Mean score of delegation, by with or without successors' own enterprise

\begin{tabular}{|c|c|c|c|c|c|c|}
\hline & & Technical & Strategic & Marketing & Financial & General \\
\hline \multirow{2}{*}{ Japan } & with & 3.20 & 3.21 & 3.19 & 2.89 & 3.14 \\
\hline & without & 1. 74 & 1. 77 & 1.75 & 1.71 & 1. 73 \\
\hline \multirow{2}{*}{ USA: Iowa } & with & 3. 38 & 3.13 & 3.09 & 2.86 & 3.12 \\
\hline & without & 1. 79 & 1. 74 & 1. 62 & 1. 59 & 1. 68 \\
\hline \multirow{2}{*}{ USA: Virginia } & with & 2.69 & 2.48 & 2.46 & 2.33 & 2. 49 \\
\hline & without & 1. 61 & 1. 63 & 1.50 & 1. 45 & 1.55 \\
\hline \multirow{2}{*}{ England } & with & 3.32 & 2.98 & 2.77 & 2.35 & 2. 86 \\
\hline & without & 2.10 & 1. 96 & 1.83 & 1. 49 & 1.85 \\
\hline Canada: & with & 3.51 & 3. 43 & 3.19 & 2.96 & 3. 28 \\
\hline Ontario & without & 2. 65 & 2. 47 & 2.32 & 2.24 & 2. 43 \\
\hline Canada: & with & 3.16 & 3.06 & 2.89 & 2.54 & 2.90 \\
\hline Quebec & without & 2.50 & 2. 39 & 2.22 & 2.08 & 2.28 \\
\hline
\end{tabular}

Source: FARMTRANSFERS.

not. The mean delegation score is higher when the successor has his/her own enterprise in all countries/states (statistically significant at the $1 \%$ level). Allowing successors to have their own enterprise therefore appears to have effects not only enabling them to acquire business management skills directly through their work on this enterprise but also by encouraging increased delegation on the farm as a whole. Policies, such as that in Japan, 7) to encourage the successor to have his/her own distinct enterprise within the farm family business helps facilitate smooth farm succession.

\section{3) The "farmer's boy" problem}

Gasson and Errington [13] characterised the successor who has worked with their parents for a long time but has been accorded few managerial responsibilities as the "farmer's boy" and regarded it as a typical problem in farm succession. Errington and Lobley [10] subsequently demonstrated that the "farmer" $\mathrm{s}$ boy" can be seen more frequently in England than in other countries covered by the FARMTRANSFERS surveys. It has been suggested that the reason why delegation is delayed in England is that the farm family business may have traditionally been regarded as the pension fund for the older generation (Errington and Lobley [10]). However, their definition of what constitutes a "farmer's boy" is open to debate. First, it can be argued that not enough consideration is given to the successor's age. If successors are still very young (say 18 years old or less), the lack of managerial responsibility simply indicates that the delegation process has not yet started. The presence of a "farmer's boy" in that case is not a significant issue. Second, if successors are involved in off-farm employment and in farming only on a part-time basis, it is natural that the delegation process is delayed. Therefore, the term "farmer's boy" should not be applied to these cases. In this paper, we refine the approach developed by Errington and Lobley and regard a successor as a "farmer's boy" when the following criteria are all satisfied; (1) the successor's age is 35 year old or over, (2) the successor is involved in farming at the home farm on a fulltime basis, and (3) the delegation score in general is lower than the mean score of successors aged 20-29 in each country. ${ }^{8)}$

Table 7 shows the present occupation of successors whose age is 35 years or over, classified by following the criteria mentioned above. Each country has its own unique characteristics. In Japan and Virginia the diversion route is common; in England and Canada the direct route is common; in Iowa the percentage of successors occupying a "stand-by farm" is much higher than in the other countries. Among these countries, England stands out because of its much higher proportion of "farmer's boy" successors. One out of six successors who are 35 years old or older, and 
Dimensions of Intergenerational Farm Business Transfers in Canada, England, the USA and Japan 43

Table 7. Present occupation of successors, aged 35 years old or over

\begin{tabular}{lcccccc}
\hline & Japan & $\begin{array}{c}\text { USA: } \\
\text { Iowa }\end{array}$ & $\begin{array}{c}\text { USA: } \\
\text { Virginia }\end{array}$ & England & $\begin{array}{c}\text { Canada: } \\
\text { Ontario }\end{array}$ & $\begin{array}{c}\text { Canada: } \\
\text { Quebec }\end{array}$ \\
\hline Full-time on this farm & 8.2 & 29.8 & 16.2 & 75.5 & 50.0 & 71.4 \\
Farmer's boy & 0.7 & 6.4 & 7.4 & 17.0 & 2.4 & 7.1 \\
Not farmer's boy & 7.5 & 23.4 & 8.8 & 58.5 & 47.6 & 64.3 \\
\hline Off farm employment & 64.3 & 29.8 & 55.9 & 5.3 & 23.8 & 3.6 \\
Manage own farm & 0.3 & 21.3 & 5.9 & 8.5 & 14.3 & 10.7 \\
Run non-farm business & 7.5 & 2.1 & 14.7 & 2.1 & 2.4 & 7.1 \\
\hline Others & 19.7 & 17.0 & 7.4 & 8.5 & 9.5 & 7.1 \\
\hline Total & 100.0 & 100.0 & 100.0 & 100.0 & 100.0 & 100.0 \\
\hline
\end{tabular}

Source: FARMTRANSFERS.

one out of five fulltime farming successors who are 35 years old or over, are classified as a "farmer's boy." In Virginia, nearly half of the successors who are involved in farming in full-time basis would be regarded as a "farmer's boy," although it should be noted that the percentage of the successors involved in farming on the home farm on a full-time basis is very low. The "farmer's boy" problem may arise for various reasons including cultural and social norms (see Salamon [29]). In addition, the expectation that the family farm will essentially provide a pension for the older generation could significantly delay delegation, the older farmer not wanting to entrust his/her 'pension' to a younger family member. In other cases policy effects may reduce the "farmer's boy" problem. Daucé, Le Hy, and Perrier-Cornet [7], for example, have pointed out that early retirement policies encourage the earlier transfer of managerial control and so help reduce the "farmer's boy" problem.

4) The remainder of the succession ladder in the last 5 years

The "farmer's boy" problem is the result of the low speed of transferring managerial control to the successor. It is caused when a farmer has not delegated sufficient managerial responsibility to the successor, even though the successor is arguably ready to assume delegated responsibility. The "farmer's boy" issue notwithstanding, the concept of the succession ladder assumes that successors ascend the succession ladder and become principal farmers when they reach the top, having all domains of managerial responsibility, including financial decisions delegated to them. Therefore, it is to be expected that the extent of delegation will be influenced by the number of years remaining before a farmer's retirement. It might be expected that the closer a farmer is to anticipated retirement age the greater the degree of delegation to the successor.

Figure 3 shows the mean remainder of the managerial delegation score in the last five years before anticipated retirement. The score of each of the four managerial domains ranges from a maximum of 20 to a minimum of 4. Therefore the "remainder score" should lie between 0 and 16. According to Figure 3, the mean remainder scores are more than 8 points except in Canada, which means the delegation progression is less than half complete in most countries even when it is less than 5 years before retirement. To accomplish the smooth transfer of farming management, in most cases successors need to rush to climb up the succession ladder before a farmer's retirement. This could be called the "last spurt" stage of succession, which must be the most crucial period of the succession process, especially in cases where a farmer is planning to fully retire. ${ }^{9)}$ If a successor, who has not had sufficient experience of taking managerial responsibility, suddenly jumps up to the top of the ladder and becomes a principal farmer, it may threaten the continuity of a farm family business, whose survivability depends on the farmer's individual capability. For successors who follow the direct route, it can be a significant challenge to cope with this last spurt period when there 


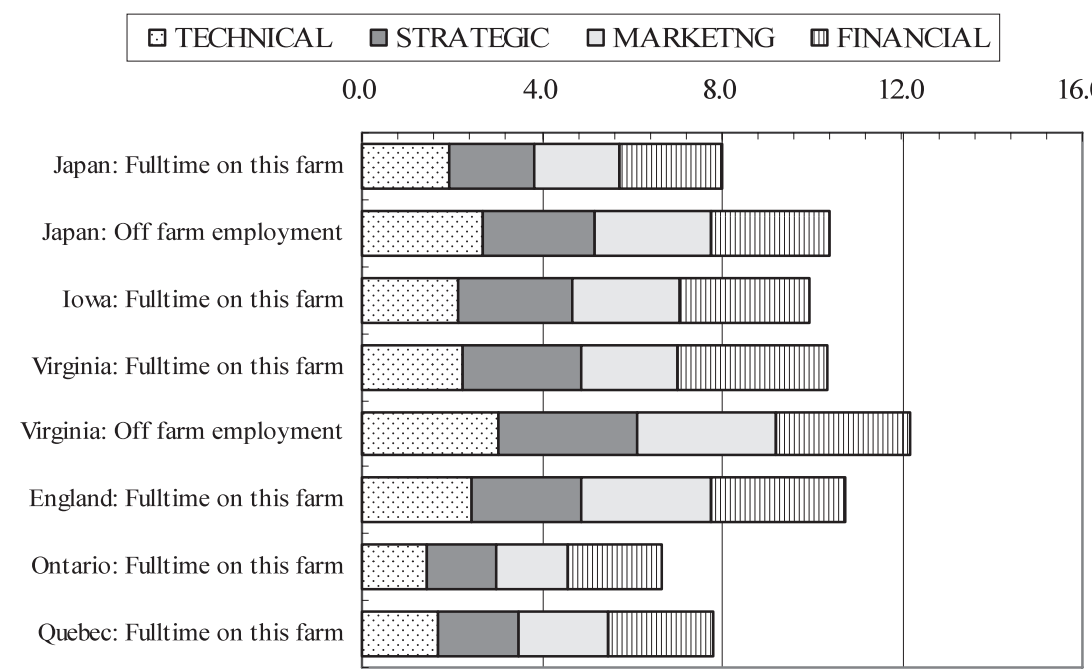

Figure 3. Mean remainder of delegation in the last 5 years, by successors' occupation Source : FARMTRANSFER.

are still many intangible resources to be delegated. This will also be the case for successors who pursue the diversion route, and who will have even less opportunity to be delegated managerial responsibility and to acquire the tacit knowledge necessary for the running of the farm.

\section{Discussion and Conclusions}

It has been widely argued (although not necessarily universally accepted) that sustaining the family farm will also help sustain rural communities and environments. Indeed, this was one of the founding principles of the CAP in the EU and this powerful idea still informs much thinking about farming, rural society and the environment. Intergenerational succession appears to remain the main entry route into farming in the countries taking part in the FARMTRANSFERS project. In addition to succeeding to managerial control of the business and eventually inheriting business assets, successors receive a transfer of detailed local agricultural and environmental knowledge. These are highly valuable, if somewhat intangible, assets. The repeated transfer of farms in a given locality down several generations of the same families results in farming families that are deeply socially embedded in their communities. These are precisely the characteristics that the earliest writers advocating the family farm model valued and wished to maintain and promote.

Within this context, this paper has focused on the farm succession process after the point at which a successor has been identified and has analysed how age and successor behaviour affect farmers' behaviour toward retirement and the delegation of managerial responsibilities. Despite some of the limitations to the approach adopted in the FARMTRANSFERS project, the analysis does show that to some extent variations in succession patterns are explained by common determinants.

With regard to the delegation of managerial responsibilities, the analysis makes it clear that successors' age and establishment of their own enterprise encourage progression in delegation. The chance to manage a separate enterprise provides ample opportunity for 'learning by doing' under the supervision of the senior farmer. On the other hand, the analysis also shows that the "farmer's boy" problem can occur for successors who take the direct route because of the low speed of transfer of managerial responsibility. In these cases progression towards becoming a knowledgeable farmer is frustrated through a lack of delegation and quite possibly also due to a failure to be exposed to the vital knowledge necessary to comprehend the inner workings of the farm. Other things being equal, 
this knowledge gap could pose a threat to the sustainability of the farm. It is therefore important that senior farmers recognise that their unwillingness to delegate responsibility to a successor (s) in a smooth and timely manner could jeopardise the longer term future of the farm and the family's connection to the land. In turn, this points to the need for much more effective outreach activities in order to deliver the message that farmers who wish to see their farm pass along the generations must pay closer attention to succession and retirement planning. Ultimately, whatever succession route is followed however, all successors are likely to encounter the "last spurt" stage of the succession process which requires the successors to rush at climbing up the succession ladder shortly before the retirement of the current senior farmers. This suggests that training programmes which assist farm succession and business management should be concentrated on this "last spurt" period.

It is also apparent that that each country has its own unique challenges. For example, the USA (Iowa and Virginia) has the lowest rate of successor identification. (The reasons for this are as yet unclear although further, in-depth, investigation is planned for Iowa.) In Japan and Virginia, more farmers intend to "never retire" and more successors take the diversion route. Finally, while the sample of farmers in England reveals both less intrafamily discussion of retirement and also extensive evidence of the "farmer's boy" problem, only Canada seems to have few problems in farm business succession. At this point we can only speculate on why this might be but in the Canadian case it could be at least partially influenced by early retirement schemes and succession planning initiatives. ${ }^{10)}$ In the case of England, it will be interesting to see whether Defra's Fresh Start initiative (designed to train new entrants and facilitate the exit of older farmers) has a similar impact.

These differences raise some intriguing questions about the 'ideal' pattern and process of farm succession, particularly in a context when life expectancy is increasing in many developed countries, farm business size is growing and the maintenance of family farms is frequently seen as essential to the sustainability of rural communities and the rural environment. For example, is full retirement or semi-retirement more desirable than the decision never to retire? Should earlier retirement be encouraged? Of the two main routes to succession what are the relative advantages and disadvantages of the direct route and diversion route? What is the relative value of standardised, general farming knowledge compared with tacit, farmspecific knowledge and knowledge gained in other occupations and pursuits? Should the speed of climbing the succession ladder be greater? And finally, is the concept of the succession ladder still valid, particularly where farm businesses are being diversified and encouraged to embrace the role of multifunctional provider of goods and services?

When we consider these matters, we find a number of remaining challenges that cannot be addressed in detail at this time. First, smooth succession will not necessarily be achieved through "fast" knowledge transfer and managerial delegation but through a "well-planned" transfer and delegation process. For example, the reason why the delegation of managerial control is delayed might be that the successor does not want to take managerial responsibilities and wants to enjoy the freedom which comes from the fact they do not have those responsibilities. Second, the most significant issue is not just smooth delegation but that the successor's knowledge or skills should be acquired smoothly. Successors might be able to acquire the general skills for farm business management through their education and offfarm experiences, but arguably, they need the opportunity to be delegated managerial responsibilities on the home farm and to gain tacit knowledge through participation, observation and "learning by doing."

Together these observations point to a range of further research areas. First, there is a need to identify more precisely and differentiate between tacit, farm-specific knowledge and skills and non farm-specific skills and to explore their relative roles in the sustainable development of family farms. Tacit, farm-specific knowledge, by definition, cannot be acquired outside a particular farm and its often intangible character means that the nature of the transfer process remains 
opaque. Knowledge and skills which are not farm-specific (i. e. standardised, codified knowledge) can be obtained by the experience of operating or being involved in another farm, through education or even through experience gained in a non-farm business. The longer term implications for the social sustainability of the farm business of these different types of knowledge and different methods of acquiring such knowledge and skills remain under-researched. It might be expected that in the EU, for example, where farmers are increasingly encouraged to become rural land-based entrepreneurs, skills and knowledge gained beyond the farm will become ever more important alongside tacit, farm-specific knowledge. In other words, sustaining the family farm in the future may involve additional non-farming skills and knowledge.

Second, to address these issues requires not only international cross-sectional studies such as the FARMTRANSFERS project, but also a range of more in-depth and qualitative approaches to reveal the tensions involved in a sector where a major objective is to pass the business on to the next generation but where, as this paper has shown, the process is often far from smooth and many farmers clearly have great difficulty in 'letting go.' Finally, this paper has focused on intergenerational succession between family members. However, it has long been recognised that "too much' family succession itself could pose a threat to the sustainability of the sector and that there are "dangers in agriculture becoming a closed shop" (Northfield [23]: p. 177). The dangers of the "closed shop" approach are principally assumed to be lower levels of innovation, less business dynamism and poorer motivation to respond to new and emerging challenges (Policy Commission of the Future of Food and Farming [25]). Further research is required to explore the "dangers of a closed shop' thesis and to examine how family farming could benefit from an injection of new blood, and equally, how new entrants could benefit from the knowledge and experience of intergenerational successors. The question of "who will manage the land' has a central role in discussions regarding sustainable rural land management. There are still many challenges remaining in re- search exploring the intergenerational sustainability of family farms.

1) Pesquin, Kimhi, and Kislev [24] points out when there is no separate pension provision, the older generation tend to regard the farm business itself as their retirement "nest-egg."

2) The reason why the percentage of 60-64 years group in Iowa is relatively high is unknown. The sample size is large enough (50), which is almost the same as the mean sample size of each of the Iowa age groups (49.6).

3) The "succession effect" refers to the impact of the expectation of succession on the farm business. Potter and Lobley [27] suggest that farms may be developed over a long period in order to provide a business capable of supporting two generations or to yield sufficient capital to establish successors on separate holdings.

4) There might be less difference for farmers between "never retire" and "full retirement" than we expect. Because "never retire" might mean "I will continue working as long as possible" and "full retirement" might mean "I will fully retire at a certain age when I may become unable to work on farming." From this viewpoint, semi-retirement would mean that farmers intentionally withdraw from commitment to farming even though they could continue working and there would be a substantial difference compared to the other two retirement options.

5) The association between labour usage and farm size is complex. Some evidence (e.g. Morison, Hine, and Pretty [20]) indicates that smaller farms employ proportionally more labour per unit area. However, there is not a simple relationship between farm size and labour. Additional factors such as farm type and farming system (e.g. organic vs non-organic) also play an important role. Nevertheless, research consistently indicates that smaller farms are less likely to secure a successor and that this is, at least in part, due to the inability of smaller farm to provide sufficient employment.

6) Items related to "labour" were not included in the analysis, as the number of the cases which employ non-family labour is small. Since decisions regarding "machinery choice and purchase" did not fall clearly into any one of the four categories they were also omitted from the analysis.

7) Japan Ministry of Agriculture, Forestry and Fishery (JMAFF) used to offer a special fund for young farmers including successors who establish their own enterprise. Recently the fund programme has been merged, which still can be 
used for this purpose.

8) There might be objections on the 3rd condition. We might consider another benchmark. This analysis applies the mean score of the successors in their 20 's, principally to ensure adequate sample size. In fact, the number of successors in their teens is only 11 in Ontario, and that of the successors aged 25 years or younger is only 16 in Virginia.

9) In the case of a farmer who is pursuing semiretirement the "last spurt" problem would be less crucial than that of full-retirement, as the successor still has the opportunity to get some advice from the retiring farmer by working together sometimes.

10) In Canada, nationwide concerns with family farm succession have been associated with the development of early retirement schemes and the development of reading materials and conferences on succession planning led by the Canadian Farm Business Management Council.

\section{References}

[1] Anderson, R. and M. Hepworth. "Retirement from Farming: Some Economic and Social Considerations, " Farm Management Review, Vol. 13, 1980, pp. 1-8.

[2] Baker, J. "Why the Obsession with Succession?" Minnesota: Minnesota Department of Agriculture: 2005.

[3] Baker, J., M. Duffy, and G. Lamberti. "Farm Succession in Iowa," Ames: Iowa State University, 2001.

[4] Blanc, M. and P. Perrier-Cornet. "Farm Take-over and Farm Entrance within the European Community," Paper presented to the colloquium: La Transmission des Exploitations Agricoles et L'installation des Agriculteurs dans la CEE, ENSA Dijon, December 10-11. 1992.

[5] Boehlje, M. D. and V. R. Eidman. Farm Management. New York: Wiley, 1984.

[6] Burton, R., L. Mansfield, G. Schwarz, K. Brown, and I. Convery. "Social Capital in Hill Farming," Aberdeen: The Macaulay Land Use Research Institute, Report to The Upland Centre. 2005.

[7] Daucé, P., A. Le Hy, and P. Perrier-Cornet. “Transmissions des exploitations agricoles et installations des agriculteurs dans la CEE," Paris: INRA Actes et Communications No. 11, 1993

[8] Dumas, C., F. Richer, and L. St.-Cyr. "Factors that Influence the Next Generation's Decision to Take Over the Family Farm," Family Business Review, Vol. 82, 1995, pp.99-120.

[9] Errington, A. J. "The Inter-Generational Transfer of Managerial Control in the FarmFamily Business: A Comparative Study in Eng- land, France and Canada," Journal of Agricultural Education and Extension, Vol. 5, 1998, pp. 123-136.

[10] Errington, A. J. and M. Lobley. "Handing Over the Reins: A Comparative Study of Intergenerational Farm Transfers in England, France, Canada and USA," Conference Paper, Agricultural Economics Society, Aberystwyth, 8-11 April, 2002.

[11] Errington, A. J. and R. B. Tranter. "Getting out of Farming? Part Two: The Farmers," Reading University Farm Management Unit, Study No. 27, 1991.

[12] Food Ethics Council. "Sustainable Farming and Food: Emerging Challenges," Food Ethics Council, Brighton, 2006.

[13] Gasson, R. and A. J. Errington. "The Farm Family Business," Wallingford: CAB International, 1993.

[14] Giles, T. and M. Stansfield. The Farmer as Manager, 2nd ed., Wallingford: CAB International, 1990.

[15] Harl, N. E. Farm Estates and Business Planning, 13th ed., Illinois: Century Communications Corp., 1996.

[16] Hastings, M. R. "Succession on Farms." Cranfield Institute of Technology, unpublished M. Sc thesis, 1984 .

[17] Kennedy, L. "Farm Succession in Modern Ireland: Elements of a Theory of Inheritance," in Rural Change in Ireland, ed by Davis, J., Institute of Irish Studies, The Queen's University of Belfast, 1999.

[18] Kurokawa, I. “Kazoku Keiei ni okeru Keiei Keisho no Jouken to Kadai (Conditions and Problems of Sustainable Family Farm Management)," Nogyo Keiei Kenkyu (Japanese Journal of Farm Management), Vol. 36, 1999, pp.4-10. (Japanese)

[19] Laband, D. and B. Lentz. "Occupational Inheritance in Agriculture," American Journal of Agricultural Economics, Vol.65, 1983, pp. 311-314.

[20] Morison, J., R. Hine, and J. Pretty. "Survey and Analysis of Labour on Organic Farms in the UK and Republic of Ireland, "International Journal of Agricultural Sustainability, Vol. 3, 2005, pp. 24-43.

[21] Nalson, J. S. Mobility of Farm Families. Manchester: Manchester University Press, 1968.

[22] National Assembly for Wales. Farming for the Future. The Government of the National Assembly for Wales, Cardiff. 2001.

[23] Northfield, Lord. "Report of the Committee of Inquiry into the Acquisition and Occupacy of Agricultural Land," Cmnd. 7599. London: HMSO. 
[24] Pesquin, C., A. Kimhi, and Y. Kislev. "Old Age Security and Inter-Generational Transfer of Family Farms, " European Review of Agricultural Economics, Vol. 26, 1999, pp. 19-37.

[25] Policy Commission of the Future of Food and Farming. Farming and Food: A Sustainable Future. London: Cabinet Office, 2002.

[26] Potter, C. and M. Lobley. Processes of Countryside Change in Britain. Countryside Survey 1990 Series, London: Department of the Environment. 1996.

[27] Potter, C. and M. Lobley. "Unbroken Threads? Succession and Its Effects on Family Farms in Britain," Sociologia Ruralis, Vol. 36, 1996, pp. 286-306.

[28] Ramos, G. "The Continuity of Family Agriculture and the Succession System: The Basque Case," Journal of Comparative Family Studies, Vol. 36, 2005, pp. 367-377.
[29] Salamon, S. Prairie Patrimony: Family, Farming and Community in the Midwest. Chapel Hill: the University of North Carolina Press, 1992.

[30] Väre, M. “Spousal Effect and Timing of Retirement," Journal of Agricultural Economics, Vol. 57, 2006, pp. 65-80.

[31] VDACS. "Let's Talk Transition." Research Presentation for Virginia Farm Bureau Federation 77th Annual Convention, December 2, 2002 [32] Winter, M. “Networks of Knowledge, " WWF-UK Agriculture Report, 1995.

[33] Yanagimura, S., T. Uchiyama, A. J. Errington, and M. Lobley. "Characteristics of Farm Transfer in Japan: An International Comparison," Discussion Paper, Agricultural Economics Society, 11-13 April, 2003.

(Received October 31, 2007; accepted January 28, 2008) 